\title{
ON-FARM ASSESSMENT OF SYSTEM PRODUCTIVITY OF WHEAT- JUTE-T. AMAN RICE CROPPING PATTERN IN SYLHET REGION
}

\author{
M.I. Nazrul \\ OFRD, Bangladesh Agricultural Research Institute (BARI), Bangladesh. \\ "Corresponding author: mi_nazrul@yahoo.com
}

Key words: Agronomic performance, land use efficiency, production potential, sustainable yield index

\begin{abstract}
The study was conducted to determine the yield and economic performance of two cropping patterns viz. IP: improved pattern (Wheat - Jute - T. aman) + improved management practice and FP: farmer's pattern (Fallow - T. aus - T. aman) + management practice. The experiment was laid out in a randomized complete block design with six dispersed replications at farmer's field in Sylhet region during two consecutive years of 2013-14 and 2014-15. Two years means data showed that the pattern with improved management practices provided $31 \%$ higher yield of $\mathrm{T}$. aman rice and also contributed more rice equivalent yield compared to farmers practice. Sustainable yield index, production efficiency, and land use efficiency were the maximum with WheatJute- T. aman cropping system. Similarly, highest mean gross margin and benefit cost ratio were attained in improved pattern. It was concluded that farmers of Sylhet region might follow Wheat (var. BARI Gom-26) - Jute (var. CVL-1) - T. aman (var. Binadhan-7) cropping system in medium high land for higher productivity and profitability.
\end{abstract}

\section{Introduction}

Fallow - T. aus - T. aman rice and Boro - Fallow - T. aman rice etc. are the important and popular cropping pattern in Hobiganj of Sylhet region. Farmers mostly cultivate rice under rainfed condition and thus, transplanting of $T$. aus depends on the onset of rainfall. The delayed transplantation of $\mathrm{T}$. aus causes late cultivation and harvesting of $\mathrm{T}$. aman rice. Due to late harvesting of $\mathrm{T}$. aman, all rabi crops are not possible to be grown. The soils under cropping pattern of these areas are generally heavy clay loams to clays and the top soil quickly becomes dry and hard after the harvest of $\mathrm{T}$. aman crop. More than $40 \%$ land remains fallow for a long time (December-May) after the harvest of $\mathrm{T}$. aman due to moisture stress (up to kharif- $\mathrm{I}$ ) in Eastern Surma-Kushiyara Floodplain (AEZ-20) and Northern and Eastern Piedmont Plain (AEZ-22). Farmers of the mentioned areas wait for cultivating $T$. aus rice following the existing cropping pattern (Fallow - T. aus - T. aman) under rainfed condition. But the weather data of study areas revealed that rainfall starts here in February and prevails up to November in each year that offers an excellent opportunity for the production of short duration crop.

BARI has been developed more than 27 wheat varieties with high yield potential and good quality. Among the BARI released wheat varieties, BARI Gom-24, BARI Gom-25, BARI Gom-26, BARI Gom-27 and BARI Gom-28 have been popularized in different areas of the country and farmers are adopting the varieties rapidly. In order to increase production, wheat can be cultivated before Jute under Wheat - Jute - $\mathrm{T}$. aman rice based cropping pattern instead of existing Fallow - T. aus - T. aman cropping pattern in AEZ-20 of Bangladesh. A number of reports on different cropping pattern are available in Bangladesh and India that indicate that an additional crop 
could be introduced without much changes or replacing the existing ones for considerable increases of productivity as well as profitability of the farmers (Wahhab and Azad, 1981; Azad et al. 1982; Malavia et al. 1986; Soni and Kaur, 1984; Khan et al., 2005 and Nazrul, et al. 2013). But, little efforts have been made for on-farm evaluation of the improved technologies of Wheat-Jute-T. aman rice cropping pattern in Sylhet area. The present study was therefore, initiated to find out the agroeconomic feasibility of an improved package of technologies over the farmers existing practices.

\section{Materials and Methods}

On-farm trials were carried with out in farmer's field under Eastern Surma - Kushiyara Floodplain (AEZ-20) which is located in between 23 $58^{\prime}$ and $24^{\circ} 16^{\prime}$ north latitudes and in between $91^{\circ} 16^{\prime}$ and $91^{\circ} 25^{\prime}$ east longitudes of Bangladesh, during two consecutive years 2013-14 and 2014-15. This trial was conducted to with two cropping patterns viz. IP: improved pattern (Wheat - Jute - T. aman) and FP: farmer's pattern (Fallow - $T$. aus - $T$. aman) through inclusion of modern high yielding varieties of Jute, $\mathrm{T}$. aman rice as well as Wheat and improved management practices for crop production.

Annual monthly total rainfall $3821 \mathrm{~mm}$ was during the period 2014-15. Average maximum and minimum temperature was 31.34 and was $14.72^{\circ} \mathrm{C}$, respectively (Fig.1). The soil was clay loam with low organic matter content $(1.30 \%)$ and soil $\mathrm{pH}$ was ranged 5.3-6.2 acidic in nature. The status of $\mathrm{N}, \mathrm{P}, \mathrm{K}, \mathrm{S}, \mathrm{B}$ and $\mathrm{Zn}$ was very low, low, low, very low and medium, respectively. The experimental design was a randomized complete block with six dispersed replications with plot size of 500 $\mathrm{m}^{2}$. One plot was under the improved pattern and the other farmer's pattern.

In the improved pattern, wheat var. BARI Gom-26 was introduced against fallow period. The var. CVL-1 of Jute and Binadhan-7 of $\mathrm{T}$. aman rice was introduced instead of BR26 and BRRI dhan33, respectively. The agronomic practices and cultural operation for crop production under improved and farmer's practices are presented in Table 1. All field operation and management practices of both farmer's and improved pattern were closely monitored and the data were recorded for agro-economic performance. The yield differences between the practices were statistically analyzed by't' test. Agronomic performance viz. land use efficiency, production efficiency, rice equivalent yield and sustainable yield index of cropping patterns were calculated by the following formula:

Land use efficiency: Land use efficiency is worked out by taking total duration of individual crop in a sequence divided by 365 days (Tomer and Tiwari, 1990). It is calculated by following formula.

$$
\text { Land use efficiency }=\frac{\mathrm{d}_{1}+\mathrm{d}_{2}+\mathrm{d}_{3}}{365} \text { Ч } 100
$$

Where $\mathrm{d}_{1}, \mathrm{~d}_{2}$ and $\mathrm{d}_{3}$ the duration of $1^{\text {st }}, 2^{\text {nd }}$ and $3^{\text {rd }}$ crops of the pattern.

Production efficiency: Production efficiency values in terms of $\mathrm{Kg}_{\text {ha }}{ }^{-1} \mathrm{day}^{-1}$ were calculated by total production in a cropping sequence divided by total duration of crops in that sequence (Tomer and Tiwari. 1990).

$$
\text { Production efficiency }=\frac{Y_{1}+Y_{2}+Y_{3}}{d_{1}+d_{2}+d_{3}}
$$


On-Farm Assessment of System Productivity of Wheat-Jute-T. Aman Rice Cropping Pattern in Sylhet Region

Where, $Y_{1}=$ Yield of $1^{\text {st }}$ crop and $d_{1}=$ Duration of $1^{\text {st }}$ crop of the pattern $\mathrm{Y}_{2}=$ Yield of $2^{\text {nd }}$ crop and $\mathrm{d}_{2}=$ Duration of $2^{\text {nd }}$ crop of the pattern $\mathrm{Y}_{3}=$ Yield of $3^{\text {rd }}$ crop and $\mathrm{d}_{3}=$ Duration of $3^{\text {rd }}$ crop of the pattern

Sustainable yield index: Sustainable yield index (SYI) was worked out by the following formula suggest by Krishna and Reddy (1997).

$$
\text { Sustainable yield index }(\mathrm{SYI})=\frac{\mathrm{Y}_{\operatorname{mean}}-\mathrm{SD}}{\mathrm{Y}_{\max }} \stackrel{\mathrm{Y}}{100}
$$

Where, $\mathrm{Y}_{\text {mean }}$ : Estimated mean yield of a practice over years; SD: Estimated standard deviation; $Y_{\max }$ : Observed maximum yield in the experiment over the years.

Rice Equivalent Yield (REY): For comparison between crop sequences, the yield of all crops was converted into rice equivalent on the basis of prevailing market price of individual crop (Verma and Modgal, 1983; Bandyopadhyay, 1984). The economic indices like gross and net returns and benefit cost ration were also calculated on the basis of prevailing market price of the produces.

Rice equivalent yield $\left(\mathrm{t} \mathrm{ha}^{-1}\right)=\frac{\text { Yield of individual crop } \times \text { Market price of that crop }}{\text { Market price of rice }}$

For economic evaluation of two different cropping sequences averaged data of two crop cycles were used. The gross cost of cultivation of different crops was calculated on the basis of different operations performed and materials used for raising the crops. Gross margin, gross return and total cost of cultivation of the component crops were calculated as well as benefit cost ratio (BCR) as per following formula.

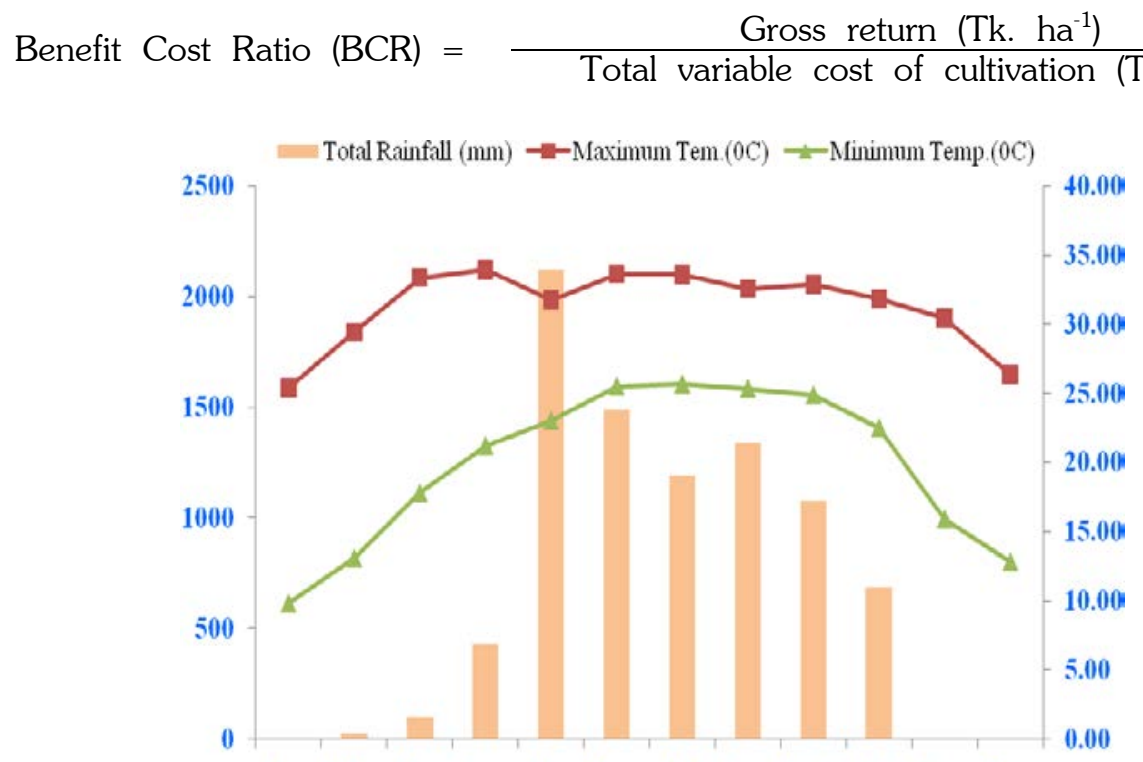

Jan. Feb. Mar. Apr. May Jun. Jul. Aug Sept. Oct. Nov. Dec.

Fig. 1. Month wise total rainfall $(\mathrm{mm})$ and temperature during study period 2013-15 in Srimangal, Moulvibazar. 


\section{Grain/Fiber Yield of the Cropping Patterns}

Improved pattern required 288-309 days against 181-190 days due to inclusion of jute instead of $\mathrm{T}$. aus rice in the pattern, but can be easily fitted before $\mathrm{T}$. aman rice (Table 1). Yield of $\mathrm{T}$. aman rice in the improved pattern was higher due to change of variety with improved production technologies (Table 2). Similar results were also obtained by Nazrul et al. (2013), Khan et al. (2006), Khan et al. (2005) and Hossain and Wahhab (1992). In both years, farmers' pattern gave lower grain yield of rice due to imbalance use of fertilizers and more plant population. The rice variety, Binadhan-7 in improved pattern performed better than BRRI dhan33 in farmers' practices due to use of balance fertilizer and modern technology.

\section{By-product Yield of the Cropping Patterns}

The improved cropping pattern produced higher amount of total by-product yield (12.95 t/ha) than the by-product yield of the crops of the farmers' pattern $(9.07 \mathrm{t}$ ha $^{-1}$ ). The by-product yield of improved pattern was higher due to introduction and change of variety with improved technologies for the component crops. In both years it was revealed that the component crops wheat and Jute of improved pattern produced valuable by-product. On the contrary, farmers are not able to sale by-product (rice straw) in the local market; whereas, the by-products of Wheat and Jute crops were valuable and high demand in the local market.

Rice equivalent yield also contributed more rice equivalent yield compared to farmers practice. The mean rice equivalent yield revealed that improved cropping pattern produced higher rice equivalent yield (13.51 $\left.\mathrm{t} \mathrm{ha}^{-1}\right)$ over farmers' traditional (7.29 t $\mathrm{ha}^{-1}$ ) cropping pattern (Table 3). On an average, the rice equivalent and $\mathrm{T}$. aman rice yield in improved pattern increased by 23.88 and $8.39 \%$, respectively over the crops of the farmers' practices (FP). Inclusion of high yielding new varieties and crops with improved management practices in the improved pattern increased the $T$. aman rice equivalent yield. It was also due to higher price of components crops in the improved pattern. Lower rice equivalent yield was obtained in the farmer's pattern due to variety and traditional management practices.

\section{Production efficiency}

Maximum production efficiency was obtained from improved pattern in each year of 2013-2014 and 2014-15 (Table 3). The higher production efficiency of improved cropping pattern might be due to introduction of new and or modern varieties and management practices. In conversely, the lowest production efficiency was observed in farmers' pattern where modern management practices were absent. Mean production efficiency (44.08) in terms of $\mathrm{kg}^{-1}$ ha-1 day was higher in improved pattern and lower (38.36) in farmers' pattern. Similar trend were noted by Nazrul et al. (2013), Khan et al. (2006), Khan et al. (2005) and Krishna and Reddy (1997).

\section{Land use efficiency}

Land use efficiency is the effective use of land in a cropping year, which mostly depends on crop duration. The average land-use efficiency indicated that improved pattern used the land for $81 \%$ period of the year, whereas farmer's pattern used the land for $50.69 \%$ period of the year. This higher land use efficiency in improved pattern is due to cultivation of wheat as component crop in fallow period.

Table 1. Management practices of improved vsfarmer's existing cropping pattern during 2013-15 
On-Farm Assessment of System Productivity of Wheat-Jute-T. Aman Rice Cropping Pattern in Sylhet Region

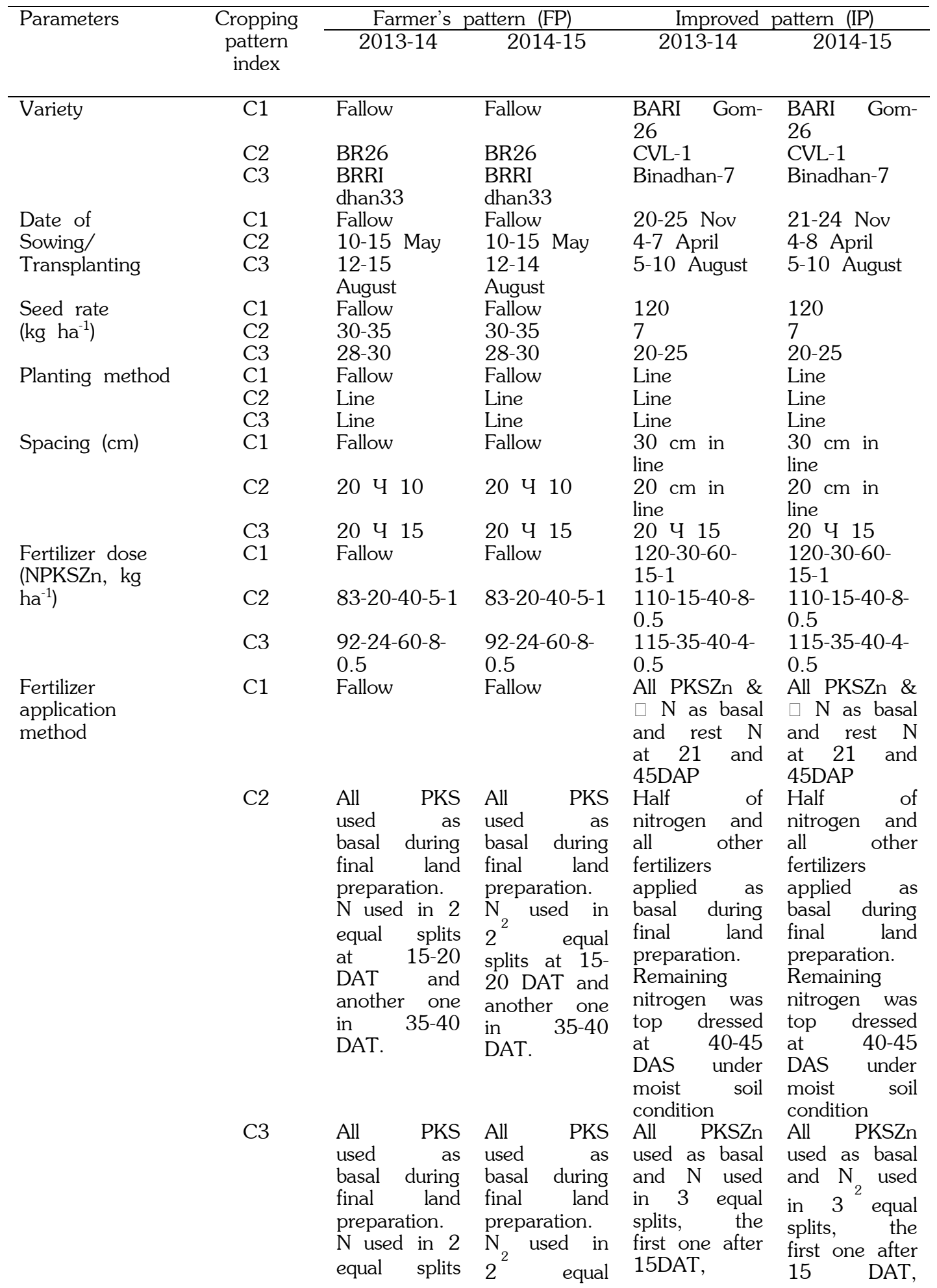


M.I. Nazrul

\begin{tabular}{|c|c|c|c|c|c|}
\hline \multirow[t]{3}{*}{ Parameters } & \multirow{3}{*}{$\begin{array}{l}\text { Cropping } \\
\text { pattern } \\
\text { index }\end{array}$} & \multicolumn{2}{|c|}{ Farmer's pattern (FP) } & \multicolumn{2}{|c|}{ Improved pattern (IP) } \\
\hline & & 2013-14 & 2014-15 & 2013-14 & 2014-15 \\
\hline & & $\begin{array}{lr}\text { at } & 15-20 \\
\text { DAT } & \text { and } \\
\text { another } & \text { one } \\
\text { in } & 35-40 \\
\text { DAT. }\end{array}$ & $\begin{array}{l}\text { splits at 15- } \\
20 \text { DAT and } \\
\text { another one } \\
\text { in } 35-40 \\
\text { DAT. }\end{array}$ & $\begin{array}{lr}\text { second } & \text { one } \\
\text { at } & 35-40 \\
\text { DAT and } \\
\text { third one at } \\
5-7 \quad \text { days } \\
\text { before } \\
\text { panicle } \\
\text { initiation } \\
\text { stage. }\end{array}$ & $\begin{array}{lr}\text { second } & \text { one } \\
\text { at } & 35-40 \\
\text { DAT and } \\
\text { third one at } \\
5-7 \\
\text { before days } \\
\text { panicle } \\
\text { initiation } \\
\text { stage. }\end{array}$ \\
\hline Weeding (no.) & $\begin{array}{l}\text { C1 } \\
\text { C2 } \\
\text { C3 }\end{array}$ & $\begin{array}{l}\text { Fallow } \\
2 \\
1\end{array}$ & $\begin{array}{l}\text { Fallow } \\
2 \\
1\end{array}$ & $\begin{array}{l}1 \\
2 \\
2\end{array}$ & $\begin{array}{l}1 \\
2 \\
2\end{array}$ \\
\hline Irrigation/Rainfed & $\begin{array}{l}\text { C1 } \\
\text { C2 } \\
\text { C3 }\end{array}$ & $\begin{array}{l}\text { Fallow } \\
\text { Rainfed } \\
\text { Rainfed }\end{array}$ & $\begin{array}{l}\text { Fallow } \\
\text { Rainfed } \\
\text { Rainfed }\end{array}$ & $\begin{array}{l}2-3 \\
\text { Rainfed } \\
\text { Rainfed }\end{array}$ & $\begin{array}{l}2-3 \\
\text { Rainfed } \\
\text { Rainfed }\end{array}$ \\
\hline $\begin{array}{l}\text { Insect-pest } \\
\text { control }\end{array}$ & $\begin{array}{l}\text { C1 } \\
\text { C2 } \\
\text { C3 }\end{array}$ & $\begin{array}{l}\text { Fallow } \\
\text { Chemical } \\
\text { Chemical }\end{array}$ & $\begin{array}{l}\text { Fallow } \\
\text { Chemical } \\
\text { Chemical }\end{array}$ & $\begin{array}{l}\text { IPM } \\
\text { IPM } \\
\text { IPM }\end{array}$ & $\begin{array}{l}\text { IPM } \\
\text { IPM } \\
\text { IPM }\end{array}$ \\
\hline $\begin{array}{l}\text { Harvest time } \\
\text { (date) }\end{array}$ & $\begin{array}{l}\text { C1 } \\
\text { C2 } \\
\text { C3 }\end{array}$ & $\begin{array}{l}\text { Fallow } \\
10-15 \text { Aug } \\
15-20 \text { Nov }\end{array}$ & $\begin{array}{l}\text { Fallow } \\
10-15 \text { Aug } \\
15-20 \text { Nov }\end{array}$ & $\begin{array}{l}\text { 17-20 March } \\
\text { 25-28 July } \\
10-16 \text { Nov }\end{array}$ & $\begin{array}{l}\text { 17-20 March } \\
\text { 25-23 July } \\
\text { 10-15 Nov }\end{array}$ \\
\hline $\begin{array}{l}\text { Field duration } \\
\text { (days) }\end{array}$ & $\begin{array}{l}\text { C1 } \\
\text { C2 } \\
\text { C3 }\end{array}$ & $\begin{array}{l}85-90 \\
96-100\end{array}$ & $\begin{array}{l}85-90 \\
96-100\end{array}$ & $\begin{array}{l}98-105 \\
100-108 \\
90-96\end{array}$ & $\begin{array}{l}98-105 \\
100-108 \\
90-96\end{array}$ \\
\hline
\end{tabular}

$\mathrm{C}_{1}$ : Fallow/Wheat; $\mathrm{C}_{2}$ : T. aus/Jute, $\mathrm{C}_{3}$ : T. aman; IPM: Integrated pest management

Table 2. Productivity of improved and farmer's existing patterns during 2013-15.

\begin{tabular}{|c|c|c|c|c|c|c|c|}
\hline \multirow[t]{2}{*}{ Years } & \multirow{2}{*}{$\begin{array}{l}\text { Cropping } \\
\text { Patterns }\end{array}$} & \multicolumn{3}{|c|}{ Grain/fiber yield $\left(\mathrm{t} \mathrm{ha}{ }^{-1}\right)$} & \multicolumn{3}{|c|}{ By product yield $\left(\mathrm{t} \mathrm{ha}{ }^{-1}\right)$} \\
\hline & & $\begin{array}{l}\text { Fallow/ } \\
\text { Wheat }\end{array}$ & $\begin{array}{c}\text { T.aus/ } \\
\text { Jute }\end{array}$ & $\begin{array}{c}\mathrm{T} . \\
\text { aman }\end{array}$ & Wheat & $\begin{array}{l}\text { T. aus/ } \\
\text { Jute }\end{array}$ & $\begin{array}{c}\mathrm{T} . \\
\text { aman }\end{array}$ \\
\hline $2013-14$ & IP & 3.83 & 2.31 & $4.13 a$ & 4.74 & 3.53 & 4.70 \\
\hline & FP & - & 3.92 & $3.75 b$ & - & 4.46 & 4.80 \\
\hline 2014-15 & IP & 3.61 & 2.26 & $3.88 \mathrm{a}$ & 4.76 & 3.34 & 4.85 \\
\hline & FP & - & 3.85 & $3.64 a$ & - & 4.38 & 4.51 \\
\hline Mean & IP & 3.72 & 2.29 & $4.01 \mathrm{a}$ & 4.75 & 3.43 & 4.77 \\
\hline & FP & - & 3.89 & $3.70 b$ & - & 4.42 & 4.65 \\
\hline
\end{tabular}

$\overline{\mathrm{FP}}=$ Farmer's pattern, $\mathrm{IP}=$ Improved pattern. Price of rice seed $=26.00 \mathrm{Tk} . \mathrm{kg}^{-1}$; Wheat seed $=35.00 \mathrm{Tk} . \mathrm{kg}^{-1}$; Jute seed $=75.00 \mathrm{Tk} . \mathrm{kg}^{-1}$; Urea $=20.00 \mathrm{Tk} . \mathrm{kg}^{-1}$; TSP $=22.00 \mathrm{Tk} . \mathrm{kg}^{-1}$; $\mathrm{MoP}=15.00 \mathrm{Tk} . \mathrm{kg}^{-1}$. Among field operations, the cost of plowing was taken as Tk. 10 decimal ${ }^{-1}$, labour cost of Tk. $300 \mathrm{man}^{-1} \mathrm{day}^{-1}$. Gross returns included income from sale of main and by-products $\left(\mathrm{Tk} . \mathrm{ka}^{-1}\right.$ ) of all crops; Price of $\mathrm{T}$. aus rice $=19.00 \mathrm{Tk}$. $\mathrm{kg}^{-1}$; $\mathrm{T}$. aman rice $=$ $20.50 \mathrm{Tk} . \mathrm{kg}^{-1}$; Jute fiber $=40.00 \mathrm{Tk} . \mathrm{kg}^{-1}$; wheat straw/haulm $=1.00 \mathrm{Tk} . \mathrm{kg}^{-1}$ and Jute stick $=5.00 \mathrm{Tk} . \mathrm{kg}^{-1}$.

\section{Sustainable yield index}

The values of sustainable yield index (SYI) as a measure of sustainability of the system which was high in the improved cropping system over farmer's practices (Table 4). It was revealed from the experimental results that between two different cropping systems Wheat-Jute-T. aman rice recorded the highest SYI of $76.41 \%$ followed by Fallow-T. aus-T. aman rice (66.10\%). It indicates that cropping system involving wheat in fallow period and Jute instead of $\mathrm{T}$. aus rice recorded higher SYI compared to 
On-Farm Assessment of System Productivity of Wheat-Jute-T. Aman Rice Cropping Pattern in Sylhet

Region

fallow-rice based crop sequences. The results are in agreement with the findings of Nazrul et al. (2013) and Ram et al., (2012). This indicated that improved pattern is therefore, more stable than farmer's pattern. Wheat and Jute are providing special advantage regarding utilization of fallow land and improving soil health, respectively.

\section{Cost benefit analysis}

Between two crop sequences, the improved cropping pattern showed its superiority over farmers' existing pattern during two consecutive years of cropping. On an average, gross return of the improved pattern was Tk.276955 ha ${ }^{-1}$ which was more than 85\% higher than farmers' pattern of TK. 149445 ha $^{-1}$ (Table 4). The production cost of the improved pattern (Tk. $131457 \mathrm{ha}^{-1}$ ) was higher than farmers' pattern (Tk. $85261 \mathrm{ha}^{-1}$ ) due to introduction of wheat in fallow and cost of fertilizer and other inputs. The gross margin was substantially higher in the improved pattern (Tk.145601 $\mathrm{ha}^{-1}$ ) than farmers' pattern (Tk. $64184 \mathrm{ha}^{-1}$ ). Inclusion of wheat and jute in these cropping systems besides, increasing the system productivity fetched higher market price thereby, increasing the gross margin. As a result, 126\% additional gross margin was achieved by adding 54\% additional cost in the improved pattern. Returns per Taka invested were highest for wheat-jute-T. aman rice (2.11) over the farmer's pattern (1.75).

Table 3. Rice equivalent yield, production efficiency, land use efficiency and sustainable yield index of improved and farmers patterns during 2013-15

\begin{tabular}{cccccc}
\hline Years & $\begin{array}{c}\text { Cropping } \\
\text { patterns }\end{array}$ & $\begin{array}{c}\text { Rice } \\
\text { equivalent } \\
\text { yield (t ha-1 })\end{array}$ & $\begin{array}{c}\text { Production } \\
\text { efficiency } \\
\left(\mathrm{kg} \mathrm{ha}^{-1} \text { day }^{-1}\right)\end{array}$ & $\begin{array}{c}\text { Land use } \\
\text { efficiency } \\
(\%)\end{array}$ & $\begin{array}{c}\text { Sustainable } \\
\text { yield index } \\
(\%)\end{array}$ \\
\hline $2013-14$ & IP & 13.83 & 44.90 & 84.38 & 73.69 \\
$2014-15$ & FP & 7.38 & 38.84 & 52.05 & 67.26 \\
& IP & 13.20 & 43.27 & 78.91 & 79.12 \\
& FP & 7.20 & 37.89 & 49.32 & 64.94 \\
\hline Mean & IP & 13.51 & 44.08 & 81.65 & 76.41 \\
& FP & 7.29 & 38.36 & 50.69 & 66.10 \\
\hline
\end{tabular}

Table 4. Cost benefit analysis of improved and farmer's existing cropping pattern during 2013-15

\begin{tabular}{cccccc}
\hline Years & $\begin{array}{c}\text { Cropping } \\
\text { patterns }\end{array}$ & $\begin{array}{c}\text { Gross return } \\
(\text { Tk. ha }\end{array}$ & $\begin{array}{c}\text { Cost of } \\
\text { cultivation } \\
(\text { Tk. ha }\end{array}$ & $\begin{array}{c}\text { Gross margin } \\
\left(\text { Tk. ha }^{-1}\right)\end{array}$ & BCR \\
\hline $2013-14$ & IP & 283515 & 131957 & 151558 & 2.15 \\
& FP & 1512900 & 85761 & 65529 & 1.76 \\
$2014-15$ & IP & 270600 & 130957 & 139643 & 2.07 \\
& FP & 147600 & 84761 & 62839 & 1.74 \\
\hline Mean & IP & 276955 & 131457 & 145601 & 2.11 \\
& FP & 149445 & 85261 & 64184 & 1.75 \\
\hline
\end{tabular}

\section{Conclusion}

Wheat - Jute - T. aman rice cropping system was found more productive, sustainable, land-use efficient, and remunerative than the existing farmers cultivated patterns under eastern Surma-Kushiyara Floodplain (AEZ-20) of Bangladesh. . Therefore, farmers of AEZ-20 could follow the Wheat (var. BARI Gom-26) - Jute (var. CVL-1) - T. aman 
(var. Binadhan-7) rice cropping system for higher system productivity and profitability in medium high land.

\section{Acknowledgements}

Authors are gratefully acknowledged Bangladesh Agricultural Research Institute, Gazipur and Metrological Department, Srimangal, Moulvibazar for providing financial help and logistic support and weather data, respectively. Thanks are resume who contributed compile and editing of the paper.

\section{References}

Ahasan, M. N., M. A. M. Chowdhury and D. A. Quadir. 2010. Variability and trends of summer monsoon rainfall over Bangladesh. J. Hydroly. and Metor. 7(1): 1-16

Alam, Q. M., M. N. Islam, A. K. M. H. Haque and T. K. Khudu. 1998. Economic profitability of growing mustard/potato as an additional crop between two rice crops in Bogora district of Bangladesh. Bangladesh J. Agril. Res. 23(4): 717-730.

Azad, A. K., F. A. H. Talukdar, M. A. Wahhab and M. A. Khan. 1993. Progress and prospect of jute based cropping systems research in Bangladesh. Proc. Expert Cons. Jute and Kenaf Improvement: pp. 244-267.

BBS (Bangladesh Bureau of Statistics) 2001. Year Book of Agricultural Statistics of Bangladesh. Bangladesh Bureau of Statistics. 22nd Edition, December 2003.

Hossain, M. A. and M. A. Wahhab. 1992. Demonstration-cum-assessment of recommended and farmer's technologies in jute cultivation. Abs. of Research. Argil. Res. on Jute, Bangladesh Jute Research Institute: p. 250.

Khan, M. A. H., M. A. Quayyum, M. I. Nazrul, N. Sultana and M. R. A. Mollah. 2005. On-farm evaluation of production potential and economics of mustard-rice based improved cropping system. J. Socio. Res. Dev. 2(1): 37-42.

Krishna, A and K.A. Reddy. 1997. Production potential and economics of different rice (Oryza sativa) - based cropping system in Andhra Pradesh. India J. Argil. Sci. 67(12): 551-553.

Malavia, D. D., M. P. Singh, M. M. Vyas, J. C. Patel and K. K. Kalaria. 1986. Production potential and economic feasibility of different crop sequences. Indian $\mathrm{J}$. Argon. 31(1): 75-78.

Nazrul, M. I., Shaheb, M. R., Khan, M. A. H. and Khan, A. S. M. M. R. 2013. OnFarm evaluation of production potential and economic returns of potato-rice based improved cropping system. Bangladesh Agron. J. 16(2): 41-50.

Ram, A. Jat, R. A. Dungrani, M. K. Arvadia and Kanwar L Sahrawat. 2012. Diversification of rice (Oryza sativa L.) based cropping systems for higher productivity, resource-use efficiency and economic returns in South Gujarat of India. Arch. of Agron.and Soil Sci. 58(6): 561-572.

Soni, P. N and R. Kaur. 1984. Studies on production potential of different cropping systems. Indian J. Agron. 29 (3): 367-78.

Tomer, S. S and A. S. Tiwari. 1990. Production potential and economics of different crop sequences. Indian J. of Agron. 35 (1, 2): 30-35.

Verma, S. P and S. C. Modgal. 1983. Production potential and economics of fertilizer application as resources constraints in maize, wheat crop sequence. Himachal $\mathrm{J}$. Agric. Res. 9 (2): 89-92. 